\title{
Mitral valve repair using the double Teflon technique in patients with severely calcified annuli and myxomatous disease
}

\author{
Plástica valvar mitral pela técnica de "Duplo Teflon" em pacientes com anel valvar calcificado e \\ degeneração mixomatosa
}

João Marcelo A.C. de ALBUQUERQUE ${ }^{1}$, Paola Y. POMERANTZEFF ${ }^{2}$, Carlos Manuel de Almeida BRANDÃO , Max GRINBERG ${ }^{4}$, Pablo M. A. POMERANTZEFF ${ }^{5}$, Sérgio Almeida de OLIVEIRA ${ }^{6}$

RBCCV 44205-743

\section{Abstract}

Objective: The purpose of this study is to present the immediate and long-term results of mitral valve repair using the double Teflon technique in patients with mitral insufficiency due to myxomatous disease and severely calcified annuli.

Method: Between 1985 and 2002, 162 patients with mitral valve insufficiency due to myxomatous degeneration were submitted to mitral valve repair in the Heart Institute of University of São Paulo Medical School. From these, 13 presented severely calcified annuli and underwent mitral valve repair with quadrangular resection and annuloplasty using the double Teflon technique. The mean patient age was $65.4 \pm 12.9$ years with $69.2 \%$ of the patients being male. One $\mathbf{( 7 . 7 \% )}$ patient had associated coronary artery disease and was submitted to coronary artery bypass grafting. In the preoperative period, $15.4 \%$ of the patients were in functional

Work performed in the Instituto do Coração - HC-FMUSP. Surgery of the Heart Valve Disease Division

Work presented at the 31st Brazilian Society of Cardiovascular Surgery Congress (Curitiba, PR - April, 2004)

1 - 5th year resident of Cardiovascular Surgery in InCor - HC-FMUSP. 2 - Student, Medicine School, University of Santo Amaro.

3 - Doctor, Surgery of the Heart Valve Unit, InCor - HC - FMUSP; $\mathrm{Ph}$. D. in Medicine, FMUSP

4 - Director, Surgery of the Heart Valve Unit, InCor - HC-FMUSP; Professor da FMUSP

5 - Director, Surgery of the Heart Valve Unit, InCor - HC-FMUSP; Professor of the Thoracic and Cardiovascular Surgery Section, Cardiopneumology Department, FMUSP

6 - Professor Thoracic and Cardiovascular Surgery Section, Cardiopneumology Department, FMUSP

Correspondence address: João Marcelo A.C. de Albuquerque. Divisão Cirúrgica de Cardiopatias Valvares Av. Dr. Enéas de Carvalho Aguiar,44. São Paulo, SP. CEP 05403-000. Phone: (11) 3069-5415. E-mail: joaomarcelo@sbccv.org.br class IV of the New York Heart Association, 69.2\% in class III and $15.4 \%$ in class II.

Results: There were no operative deaths. In late postoperative period $90.9 \%$ of the surviving patients were in functional class I. There were no episodes of hemolysis or endocarditis. One patient was reoperated in the second postoperative month and was submitted to mitral valve replacement. The actuarial survival at 14 years was $71.4 \% \pm$ $17.1 \%$.

Conclusions: Mitral valve repair using the double Teflon technique in patients with myxomatous disease and severely calcified annuli presented satisfactory survival rates and good clinical evolution which proved to be a better alternative than mitral valve replacement.

Descriptors: Mitral valve insufficiency, surgery. Mitral valve, surgery. Heart valves, surgery. Calcinosis. 


\section{Resumo}

Objetivo: O objetivo deste estudo é apresentar resultados imediatos e tardios da plástica da valva mitral pela técnica de Duplo Teflon, em pacientes com insuficiência mitral importante que apresentam anel valvar gravemente calcificado e degeneração mixomatosa.

Método: Entre 1985 e 2002, 162 pacientes com insuficiência mitral devido à degeneração mixomatosa foram submetidos a plástica da valva mitral no Instituto do Coração da Faculdade de Medicina da Universidade de São Paulo. Deste total, 13 pacientes que apresentavam anel valvar gravemente calcificado foram submetidos à plástica da valva com ressecção quadrangular e anuloplastia pela técnica de Duplo Teflon. A idade média dos pacientes foi $65,4+/-12,9$ anos, e $69,2 \%$ dos pacientes eram do sexo masculino. Um $(7,7 \%)$ paciente tinha doença coronariana associada e foi submetido à cirurgia de revascularização do miocárdio. No período pré-operatório, $15,4 \%$ dos pacientes estavam em classe funcional IV, $69,2 \%$

\section{INTRODUCTION}

Prolapse of the mitral valve caused by myxomatous degeneration can be associated to calcification of the mitral annulus, principally in elderly patients and evolve with a variety of clinical syndromes [1]. These include mitral valve insufficiency to varying degrees. The most frequent mechanism of this insufficiency is elongation or rupture of cords [2] a disease that today is treated by valvuloplasty [3]. In several countries, this is the most frequent cause of mitral insufficiency [4-6]. In our 12 years of experience, myxomatous degeneration is the etiology in $25.9 \%$ of patients submitted to mitral valvuloplasty [7].

In 1966, Criley et al. [8] introduced the term prolapse to their cineangiographic descriptions, when they found marked bulging of the posterior cuspid of the mitral valve into the left atrium at ventricular systole ("billowing"), or multiple bulging ("floppy") of the posterior cuspid.

The real prolapse, according to Cheng and Barlow [9], signifies lack of adequate coaptation with dislocation of the affected cuspid inside the left atrium with mitral insufficiency.

Progressive mitral insufficiency is found in approximately $5 \%$ of patients who suffer from mitral valve prolapse. The occurrence of prolapse in the healthy population depends on the method utilized for diagnosis. By auscultation alone, the incidence varies of $1.4 \%$ to $6.3 \%$. If echocardiography is utilized, approximately $21 \%$ of young women have this diagnosis [10].

In the studies of Framigham, mitral valve prolapse was described as the most frequent diagnosis of abnormality of heart valves in the United States of America. Estimates of prevalence vary from $5 \%$ to more than $15 \%$ [11]. Clinical studies have suggested that mitral valve prolapse, in many patients, constitutes a syndrome that prevails in older em classe III e $15,4 \%$ em classe II.

Resultados: Não houve óbito no período pós-operatório imediato. No período pós-operatório tardio, $\mathbf{9 0 , 9 \%}$ dos pacientes vivos estavam em classe funcional I. Não houve complicações como hemólise ou endocardite. Um paciente foi reoperado no segundo mês do período pós-operatório sendo realizada troca da valva mitral. A sobrevida atuarial em 14 anos foi $71,4+/-17,1 \%$.

Conclusão: A plástica da valva mitral com a técnica de Duplo Teflon, em pacientes com insuficiência mitral importante devido à degeneração mixomatosa e anel valvar gravemente calcificado, apresentou taxa de sobrevida satisfatória e boa evolução clínica, sugerindo ser melhor alternativa em relação à troca valvar.

Descritores: Insuficiência da valva mitral, cirurgia. Valva mitral, cirurgia. Valvas cardíacas, cirurgia. Calcinose.

individuals with thoracic wall bone abnormalities [12].

Deverreux et al. [13] described an incidence of prolapse of $4 \%$ in a population of 2146 individuals. The risk of bacterial endocarditis in patients with prolapse was $4.6 \%$, and with a $41.4 \%$ rate of rupture of cords. There was a prevalence of complications in men with a ratio of 7.4:2.5 in relation to women. Patients with mitral insufficiency and rupture of cords were significantly older than those who did not present with complications.

Hill et al. [14] found 5\% of mitral valve prolapse in 294 necropsies routinely made in the St. Georges Hospital in London.

The smaller operative morbid-mortality rates, minor thromboembolism and endocarditis rates [15], better survival rates, preservation of left ventricular function, a lesser necessity of anticoagulation and lower costs [16-18] are considered to be the advantages of valve reconstruction over replacement.

The objective of this study was to present the immediate and long-term results of mitral valvuloplasty using the double Teflon technique, in patients with significant mitral insufficiency associated with calcification of the valvar annulus and myxomatous degeneration.

\section{METHOD}

Between 1985 and 2002, 162 patients with mitral insufficiency due to myxomatous degeneration were submitted to mitral valvuloplasty in the Instituto do Coração, Medical School, University of São Paulo. The work was approved by the Scientific Research Commission of the institution (FMUSP) and by Ethics Committee of the Hospital das Clínicas, FMUSP.

Of this total, 13 patients who presented with severely 
calcified valvar annuli were submitted at valvuloplasty with quadrangular resection using the double Teflon technique [19] - Figure 1. The mean age of the patients was $65.4 \pm 12.9$ years. Of the total, $69.2 \%$ were men and $30.8 \%$ women. One (7.7\%) patient had associated coronary artery disease and was submitted to coronary artery bypass surgery.

In the pre-operative period, two (15.4\%) patients were in functional class IV of the New York Heart Association (NYHA), nine (69.2\%) were in class III and two (15.4\%) were in class II.

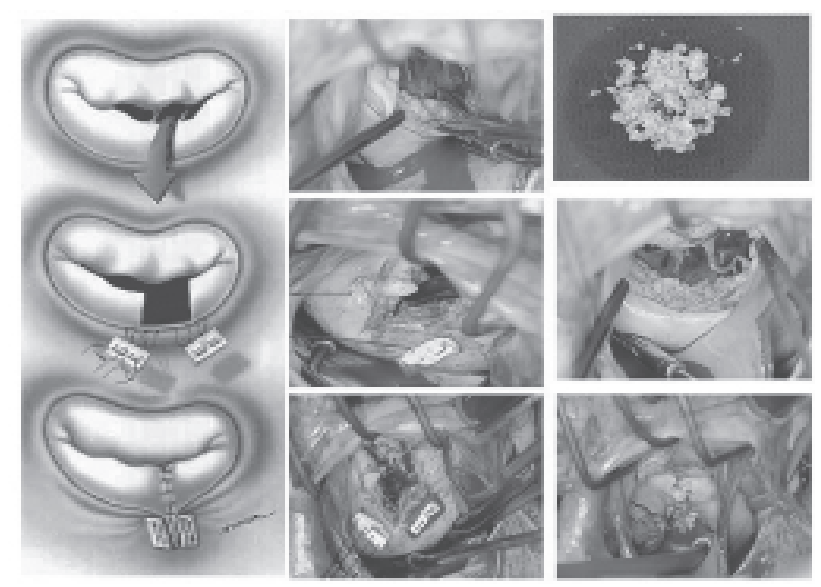

Fig. 1 - Quadrangular Resection: the Double Teflon Technique

\section{RESULTS}

There were no deaths during the immediate postoperative period. In the long-term post-operative period, $90.9 \%$ of surviving patients were in functional class I (Figure 2 ). There were no complications such as hemolysis or endocarditis. One patient was re-operated on in the second post-operative month for mitral valve replacement. The free from re-operation survival rate at 14 years was $92.3 \% \pm 7.4 \%$ (Figure 3). Two (15.3\%) patients died in the late postoperative period. The actuarial survival rate at 14 years was $71.4 \% \pm 17.1 \%$ (Figure 4 ).

The myxomatous degeneration of the mitral valve was confirmed by anatomopathological examinations of all the patients of the present study.
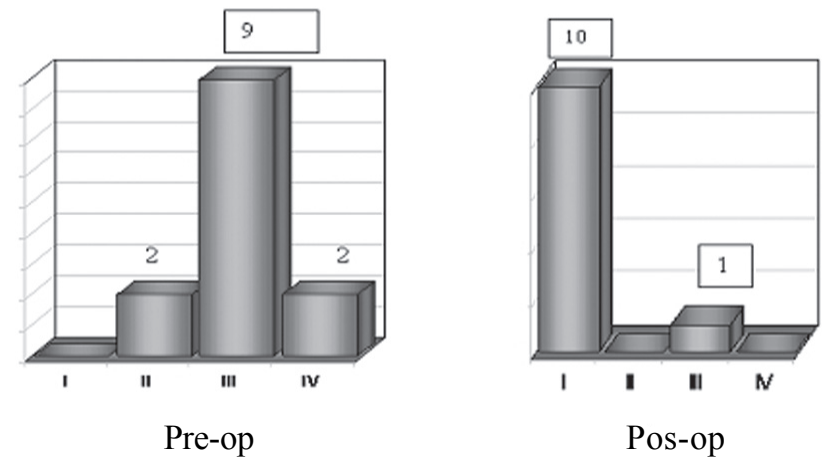

Fig. 2 - Pre and post-operative functional class (NYHA)

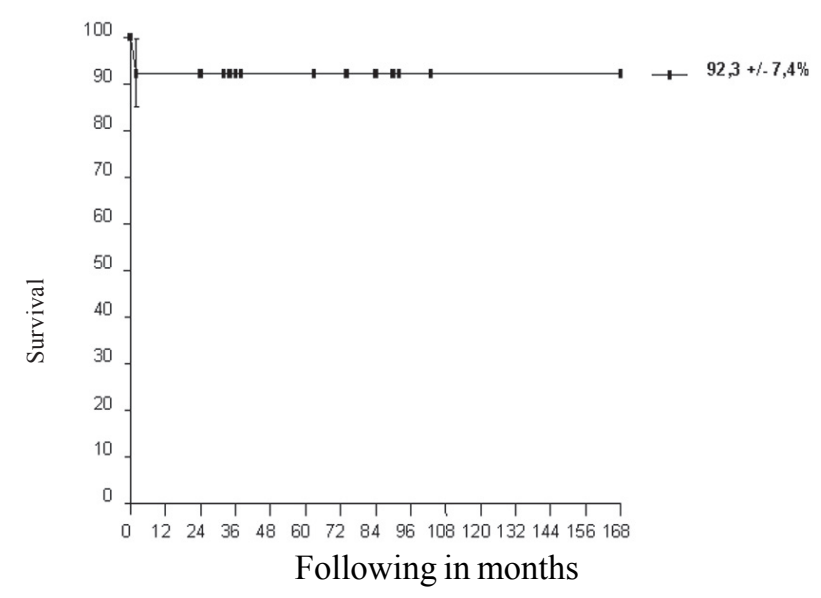

Fig. 3 - Survival free of re-operation

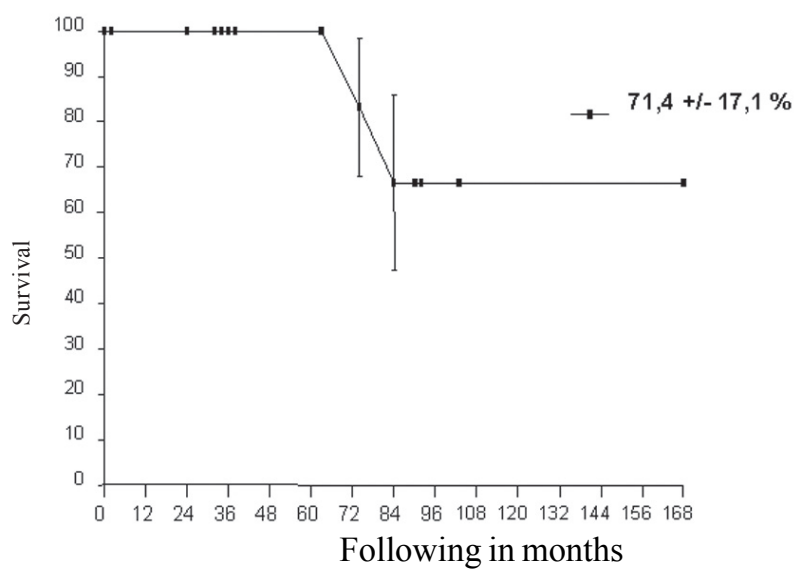

Fig. 4 - Actuarial survival 


\section{COMMENTS}

In spite of attempts to produce more and more sophisticated mechanical prostheses through biomedical engineering [20], they are still not ideal and the durability of bioprostheses is a challenge that continues for those who work to preserve biological tissues.

The replacement versus repair controversy, in selected mitral patients, has existed for many years $[1,21]$ and demonstrates the merits relative to both procedures. Akins et al. [5], after multivariate regression analysis of 263 consecutive patients submitted to mitral valve surgery for degenerative diseases, found that mitral valve replacement by itself is an important predicting factor of hospital mortality.

Degenerative disease of the mitral valve is the most common cause of mitral insufficiency in industrialized countries. Conservative surgery of the mitral valve is the standard treatment in these cases.

David et al. [6] studied 184 patients with degenerative mitral valve disease operated on between 1981 and 1992, with an estimated survival rate of $88 \pm 4 \%$ over 8 years and an estimated rate of survival free of re-operation of $95 \pm 2 \%$. These authors affirm that the mitral valvuloplasty for mitral insufficiency due to myxomatous degeneration is feasible for most patients and associated to low morbid-mortality rates. The long-term results indicate excellent survival rates and low risk of significant problems in the post-operative period.

Alvarez et al. [4] demonstrated an estimated survival free of re-operation of $90.1 \pm 4 \%$ over 10 years and $84.9 \pm$ $11 \%$, over 15 years, employing the technique of quadrangular resection of the posterior cuspid and annuloplasty without the use of a prosthetic annulus, exactly as in our technique. The authors stressed that the stability of the posterior annulus is the key to success of repair by quadrangular resection with an annuloplasty directed at removing the tension in the reconstructed cuspid. In the experience of the authors, the positioning of individual sutures on the ring achieves the objectives. As a consequence of this procedure, the posterior cuspid of the mitral valve becomes a 'platform' against which the anterior cuspid opens and closes. Using bidimensional echocardiogram, the valve has the appearance of a monocuspid. The authors also emphasize that this technique does not affect the mobility of the anterior cuspid and that by not using a prosthetic annulus shortens the time of the operation, facilitating its reproducibility.

It is well known that the mitral annulus acquires different shapes during the cardiac cycle and that it undergoes dynamic contraction [22]. The utilization of prosthetic rings, in particular rigid rings, makes its normal contraction difficult.

Studies found signs of better left ventricular function when flexible rings were utilization during mitral annuloplasty, giving a greater reduction of the left ventricle final systolic diameter, as well as of the final systolic volume [23].

Calcification of the mitral annulus in myxomatous valves is a degenerative process that involves the fibrous skeleton of the heart, resulting in an increase of stress in the mitral valvar apparatus. Massive calcification of the mitral valvar annulus is found in $0.2 \%$ of necropsies of over 51 -year-old patients, with a greater incidence in women [11].

The calcified mitral annulus represents a challenge both in valvuloplasty and in valve replacement. The incidence of left atrioventricular rupture is great, principally when extensive decalcification of the posterior annulus of the valve is made. During valvuloplasty, according to Bichell et al. [24], decalcification is possible without additional risk. Between 1980 and 1993, in the Brigham and Women's Hospital of Boston, United States of America, in a series of 252 patients submitted to valvuloplasty owing to myxomatous degeneration, 14 patients presented significant calcification of the posterior annulus. Utilizing annulus decalcification and the movement of the posterior cuspid after quadrangular resection there were no deaths or postoperative complications.

The technical difficulty of preserving the valve when a calcified mitral annulus is involved can be a challenge. However, Carpentier et al. [25] demonstrated that it is possible to perform mitral valvuloplasty in this type of patient with good results.

In our series, the mitral valvuloplasty by the double Teflon technique, as recommended by Pomerantzeff et al. [19], proved to be simple and easy to reproduce. The result was satisfactory and the patients had a good clinical evolution.

\section{CONCLUSION}

Mitral valvuloplasty using the double Teflon technique, in patients with mitral insufficiency due to myxomatous degeneration associated to a calcified valvar annulus, presented with a satisfactory survival rate and good clinical evolution, suggesting it to be a good alternative in the valvar surgery treatment.

\section{BIBLIOGRAPHIC REFERENCES}

1- Yacoub M, Halim M, Radley-Smith R, McKay R, Nijveld A, Towers M. Surgical treatment of mitral regurgitation caused by floppy valves: repair versus replacement. Circulation. 1981;64(2 pt 2):II210-6.

2- Olson LJ, Subramanian R, Ackermann DM, Orszulak TA, Edwards WD. Surgical pathology of the mitral valve: a study of 712 cases spanning 21 years. Mayo Clin Proc. 1987;62(1):22-34. 
3- Enriquez-Sarano M, Schaff HV, Orszulak TA, Tajik AJ, Bailey KR, Frye RL. Valve repair improves the outcome of surgery for mitral regurgitation: a multivariate analysis. Circulation. 1995;91(4):1022-8.

4- Alvarez JM, Deal CW, Loveridge K, Brennan P, Eisenberg R, Ward $\mathrm{M}$ et al. Repairing the degenerative mitral valve: ten to fifteen- year follow-up. J Thorac Cardiovasc Surg. 1996;112(2):238-47.

5- Akins CW, Hilgenberg AD, Buckley MJ, Vlahakes GJ, Torchiana DF, Daggett WM et al. Mitral valve reconstruction versus replacement for degenerative or ischemic mitral regurgitation. Ann Thorac Surg. 1994;58(3):668-76.

6- David TE, Armstrong S, Sun Z, Daniel L. Late results of mitral valve repair for mitral regurgitation due to degenerative disease. Ann Thorac Surg. 1993;56(1):7-14.

7- Pomerantzeff PMA, Brandão CMA, Monteiro ACM, Nersessian AC, Zeratti AE, Stolf NAG et al. Plástica da valva mitral: resultados tardios de doze anos de experiência e evolução das técnicas. Rev Bras Cir Cardiovasc. 1994;9(1):22-8.

8- Criley JM, Lewis KB, Humphries JO, Ross RS. Prolapse of the mitral valve: clinical and cine- angiocardiographic findings. Br Heart J. 1966;28(4):488-96.

9- Cheng TO, Barlow JB. Mitral leaflet billowing and prolapse: its prevalence around the world. Angiology. 1989;40(2):77-87.

10- Weiner BH, Alpert JS. Mitral regurgitation: mitral valve prolapse. In: Dalen JE, Alpert JS, editors. Valvular heart disease. 2nd ed. Boston:Little, Brown and Company;1987. p.177-95.

11- Savage DD, Garrison RJ, Devereux RB, Castelli WP, Anderson SJ, Levy D et al. Mitral valve prolapse in the general population. 1. Epidemiologic features: the Framingham Study. Am Heart J. 1983;106(3):571-6.

12- Savage DD, Devereux RB, Garrison RJ, Castelli WP, Anderson SJ, Levy D et al. Mitral valve prolapse in the general population. 2. Clinical features: the Framingham Study. Am Heart J. 1983;106(3):577-81.

13- Devereux RB, Perloff JK, Reichek N, Josephson ME. Mitral valve prolapse. Circulation. 1976;54(1):3-14.
14- Hill DG, Davies MJ, Braimbridge MV. The natural history and surgical management of the redundant cusp syndrome (floppy mitral valve). J Thorac Cardiovasc Surg. 1974;67(4):519-25.

15- Antunes MJ, Kinsley RH. Mitral valve annuloplasty: results in an underdeveloped population. Thorax. 1983;38(10):730-6.

16- Pomerantzeff PMA, Amato M, Stolf NAG, Marcial MB, Grinberg M; Pileggi F et al. Experiência com plástica de valva mitral. Arq Bras Cardiol. 1985;45(Supl I):156 (Resumo).

17- Westaby S. Preservation of left ventricular function in mitral valve surgery. Heart. 1996;75(4):326-9.

18- Barlow CW, Imber CJ, Sharples LD, Heriot AG, Wells FC, Large SR. Cost implications of mitral valve replacement versus repair in mitral regurgitation. Circulation. 1997;96(9 Suppl):II90-5.

19- Pomerantzeff PM, Brandão CM, Souza LR, Vieira ML, Grimberg M, Ramires JAF et al. Posterior mitral leaflet repair with a simple segmental annulus support: the "Double-Teflon technique". J Heart Valve Dis. 2002;11(2):160-4.

20- Baudet EM, Puel V, McBride JT, Grimaud JP, Roques F, Clerc $\mathrm{F}$ et al. Long-term results of valve replacement with the St. Jude Medical prosthesis. J Thorac Cardiovasc Surg. 1995;109(5):858-70.

21- Sand ME, Naftel DC, Blackstone EH, Kirklin JW, Karp RB. A comparison of repair and replacement for mitral valve incompetence. J Thorac Cardiovasc Surg. 1987;94(2):208-19.

22- Davis PK, Kinmonth JB. The movements of the annulus of the mitral valve. J Cardiovasc Surg. 1963;45:427-31.

23- David TE, Komeda M, Pollick C, Burns RJ. Mitral valve annuloplasty: the effect of the type on left ventricular function. Ann Thorac Surg. 1989; 47(4):524-8.

24- Bichell DP, Adams DH, Aranki SF, Rizzo RJ, Cohn LH. Repair of mitral regurgitation from myxomatous degeneration in the patient with a severely calcified posterior annulus. J Card Surg. 1995;10(4 pt 1):281-4.

25- Carpentier AF, Pellerin M, Fuzellier JF, Relland JY. Extensive calcificaton of the mitral valve annulus: pathology and surgical management. J Thorac Cardiovasc Surg. 1996;111(4):718-30. 